\title{
TO SUBSTANTIATION OF THE LIST OF HAZARDOUS HIGHLY TOXIC CHEMICALS THAT ARE SUBJECT TO SPECIAL CONTROL REGARDING HANDLING, STORAGE, USE AND DISPOSAL Part 1 (ricin, thallium compounds and organophosphorus compounds)
}

\author{
M. Prodanchuk1, G. Balan', O. Kravchuk', P. Zhminko', I. Maksymchuk², N. Chermnykh \\ 'L.I. Medved's Research Centre of Preventive Toxicology, Food and Chemical Safety, Ministry of \\ Health, Ukraine (State Enterprise), Kyiv, Ukraine \\ ${ }^{2}$ National Police of Ukraine, Kyiv, Ukraine
}

\begin{abstract}
The Aim of the Research. Based on an analytical review of literature data, to identify a group of highly toxic chemicals which over the past decades are most often used in deliberate criminal and suicidal incidents, sabotage and terrorist act; the traffic, storage, use and disposal of which must be especially carefully monitored by law enforcement agencies.

Materials and Methods. An analytical review of scientific publications was carried out using the abstract databases of scientific libraries Pub Med, Medline and text databases of scientific publishing houses Elsevier, Pub Med, Central, BMJ group as well as other VIP databases. Methods of systemic, comparative, and content analysis were used.

Results and Conclusions. The scientific publications on hazardous highly toxic chemicals, which over the past quarter century are most often used in the world, notably in deliberate criminal and suicidal incidents, sabotage, and terrorist acts, are being analysed. It was found that these chemicals mainly include ricin, thallium compounds, organophosphorus compounds, as well as chemical warfare agents, arsenic and its compounds, cyanides, and inorganic water-soluble mercury compounds (mercury bichloride, sodium merthiolate), as well as paraquat and diquat pesticides. Based on the analysis of their toxicity, clinical and morphological expression of intoxication with various routes of entry into the body, the need to include them in the List of Highly Hazardous Chemicals, whose traffic, storage, use, and disposal require stricter control of law enforcement agencies, is justified. The first part of this article presents ricin, thallium compounds, organophosphorus compounds, and chemical warfare agents.
\end{abstract}

Key Words: hazardous highly toxic chemicals, ricin, thallium compounds, organophosphorus compounds.

Introduction. An important factor in social and economic relations in the use of hazardous chemicals is the creation and functioning of mechanisms for restraining and legal regulation of their traffic, as well as the determination of punitive measures in case of violation of established norms and rules.

In previous publications we focused on this issue and described the consequences of deregulation of legislation in the handling of toxic substances [3], which arose due to the intensification of European integration processes in Ukraine, in more detail. To deepen the cooperation with international organizations for the development of small and medium-sized businesses and industry, Ukraine has undertaken to bring the legislation of Ukraine in line with the requirements of the European Union's legislation, in particular on energy efficiency and cleaner production. In this regard and in order to implement the Plan, the Government of Ukraine adopted Resolution №405 of September 3, 2014 "On invalidating certain resolutions of the Cabinet of Ministers of Ukraine" [7], where, among others, the Resolution of the
Cabinet of Ministers of Ukraine of June 20, 1995 №440 (hereinafter - Resolution №440), which approved the Procedure to obtain a permit for the production, storage, transportation, use, burial, destruction and disposal of toxic substances, including products of biotechnology and other biological agents; and which contained the List of poisonous substances, including products of biotechnology and other biological agents, the production, storage, transportation, use, burial, destruction and disposal of which are carried out with a permit (hereinafter referred to as the List) [8].

This List significantly simplified and legally guaranteed the powers of law enforcement agencies and expert institutions that documented crimes related to violation of the rules for handling toxic substances. But after the invalidation of this List, unfortunately, the positions, priorities, and advantages in the activities of lawyers were strengthened, namely concerning lawyers participating in the pretrial investigation, as well as during judicial consideration of criminal proceedings, protecting persons who negligently handle or ille- 
gally use poisonous substances, which are undoubtedly a source of public danger, threat to human health and life. But, regrettably, there is no legislative definition of the term for such a threat in the legal field.

This circumstance practically casts doubt on the legitimacy of the activities of the pretrial investigation bodies to document crimes related to the traffic of toxic substances. This fact gives bonuses to the suspect's defence side. In the case of bringing criminal proceedings to trial, which happens extremely rarely, their work is reduced to nothing due to the lack of a judicial perspective, because social, economic, and legal relations in this area are uncertain and disordered. Currently, the Cabinet of Ministers of Ukraine is considering the "List of toxic substances, including products of biotechnology and other biological agents" under №27421/10/1-18, which includes 485 names of chemicals and their compounds. They must be subject to appropriate regulatory control, in particular at the stages of entry into the country, both legal and illegal production, manufacture, shipment, storage, transportation, use, destruction, and disposal in accordance with EU legislation. Along with an extended list of hazardous chemicals in each country (including the post-Soviet countries), it has been legislatively approved a list of 6-7 highly toxic hazardous chemical compounds, which over the past 25 years are most often used in the world in criminal and suicidal incidents, sabotage, and terrorist acts, and that require stricter regulatory control. The danger lies in the fact that these highly hazardous chemicals enter the country not so much through the customs border as through smuggling. They are disseminated through advertisements on the Internet and often manufactured in illegal laboratories.

Analysis of foreign and Ukrainian literature has shown that during this time, in criminal and suicidal incidents, sabotage and terrorist acts, the following chemicals are mainly used; they are ricin, thallium, organophosphorus compounds (Ops) and chemical warfare agents (CWA), cyanides, pesticides paraquat and diquat, arsenic and inorganic mercury compounds (mercury bichloride, sodium merthiolate).

The Aim of the research. Based on an analytical review of literature data, to identify a group of highly toxic chemicals which over the past decades are most often used in criminal and suicidal incidents, sabotage, and terrorist acts in the world; the traffic, storage, use and disposal of which require particularly strict control of law enforcement agencies.

Materials and Methods. An analytical review of scientific publications was carried out using the abstract databases of scientific libraries Pub Med, Medline and text databases of scientific publishing houses Elsevier, Pub Med, Central, BMJ group as well as other VIP databases. Methods of systemic, comparative, and content analysis were used.

\section{Results and Conclusions}

1. Ricin. Ricin is found in the seeds of the castor-oil plant (Ricinus communis, R. communis) and is one of the most highly toxic substances. Castor-oil plant grows widely in tropical regions and has been cultivated since ancient times to produce castor oil as a laxative and fuel for oil lamps [9, 10]. Currently, castor-oil plant is used in medicine for the development of anticancer drugs, in the production of laxative from castor oil, as well as for cosmetics, paints, oils and other industrial products $[9,10,11]$. The main producers of castor beans are China, India, Bangladesh, and the USA, where they are widely used to obtain castor oil. There is no ricin in the oil itself; the technology of its production includes inactivation of the toxin by heating.

Purified ricin is a white, odourless powder that is highly soluble in water and retains toxic properties over a wide range of $\mathrm{PH}$. In aqueous solutions, ricin is inactivated at a temperature of $80^{\circ} \mathrm{C}$ within an hour; in dry form, it is more stable $[10,11,12]$.

The molecular weight of ricin is $60-65 \mathrm{kDa}$. Ricin, like cholera and pertussis toxins, is a binary toxin. It belongs to the A-B family, which has two functionally different polypeptide chains A and B. Chain A is ricin A toxin or RTA; it has a molecular weight of $32 \mathrm{kDa}$, and chain $\mathrm{B}$, known as ricin $\mathrm{B}$ toxin or RTB, has a molecular weight of $34 \mathrm{kDa}[9,10,25]$. Chains $\mathrm{A}$ and $\mathrm{B}$ are linked by a disulphide bond. The amount of ricin toxin and its isoforms depends on the castor-oil plant variety, its maturity, and growing conditions. The best-known isoforms of ricin toxin include R. Communis agglutinin (RCA), ricin D (RTD) and ricin E (RTE). Agglutinin R. Communis binds to erythrocytes and causes their agglutination and haemolysis $[9,10,11]$. The subunits of ricin A and B, as 
such, are not toxic, the toxic effect is present only when the two subunits interact in the ricin molecule. The B-chain is a lectin that binds to galactose on the surface of the target cell, causing endocytosis and the penetration of the ricin molecule into the cell $[9,10,11]$. From the early endosome, the B-chain of ricin promotes penetration into the trans-Golgi network (Fig. 1) [11]. In turn, the A-subunit of ricin is a highly effective $\mathrm{N}$-glycosidase. Its action is aimed at inactivating a specific adenine base (A4324) near the 3-end of 28S ribosomal RNA. One ricin A-subunit is capable of inactivating about 1500 ribosomes per minute, because of which the aminoacyl-transport RNA does not bind to the truncated $28 \mathrm{~S}$ ribosomal RNA, protein synthesis in the cell stops and the mechanism of premature apoptosis starts [10, 11, 12, 15], which causes direct cytotoxic act.

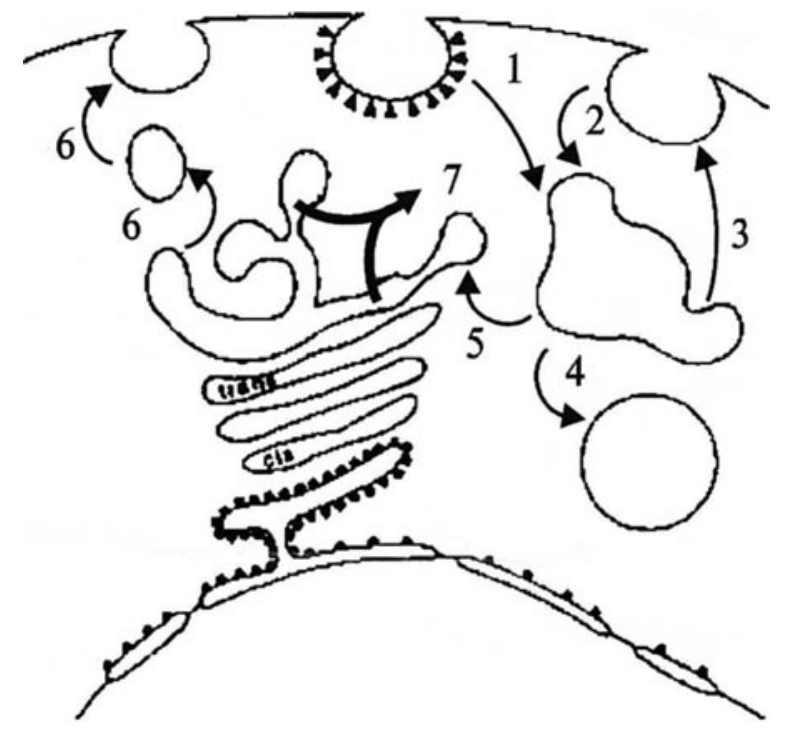

Fig. 1. The mechanism of toxic action of ricin. After the interaction of the B-subunit of ricin with galactose or N-Acetylgalactosamine on the cell surface, the toxin molecule undergoes endocytosis $(1,2)$. Most of the ricin molecules are released back to the cell surface through the mechanism of exocytosis (3). If the vesicles fuse with lysosomes, then ricin is destroyed by the proteolysis mechanism (4). Some of the vesicles containing ricin fuse with the transGolgi network (TGN) (5), from there they can also be removed to the cell surface (6). The toxic effect of ricin occurs when its molecule breaks down into subunits, then the A-subunit penetrates the TGN membrane and enters the cytosol (7), where it catalyses the depurination of ribosomes, stopping protein synthesis. (Bigalke H, Rummel A, 2005) [11].
Lethal doses of ricin depend on the method of administration into the animal's body, on the type of animal, on the degree of purification of ricin, on the conditions of its storage and the presence of isoforms in the preparation. $\mathrm{LD}_{50}$ of fine aerosol of purified ricin (aerosol particle size 1-5 microns) for rats in the range of 4,54-12,7 $\mathrm{mg} \mathrm{min} / \mathrm{m}^{3}\left(\mathrm{LD}_{50} 3,7-\right.$ $9,8 \mathrm{mg} / \mathrm{kg}$ ) [13, 14]. Lethal doses of ricin in case of inhalation injury for rhesus monkeys and African green monkeys were 15,0 and 5,8 $\mathrm{mg} / \mathrm{kg}$ [14]. The minimum inhalation lethal dose of a fine aerosol of ricin for humans is about $4 \mathrm{mg} / \mathrm{kg}[14,26]$. In case of enteral poisoning for humans, the $\mathrm{LD}_{50}$ of ricin is $1-$ $20 \mathrm{mg} / \mathrm{kg}[10,11,12]$. A decrease in the toxicity of ricin when it enters the body through the gastrointestinal tract is due to its inactivation by gastric juice and pancreatic enzymes. Poisoning symptoms and cause of death depend on the site of application of the toxin [9-22]. The clinical and paraclinical manifestations of ricin toxicity in animals depend on the route of administration. Intramuscular injections cause severe localized pain, tissue hardening at the injection site with necrosis of muscles and regional lymph nodes, followed by the formation of systemic lesions in a dosedependent manner. At high doses, damage to the liver, kidneys, gastrointestinal tract, cardiovascular system is formed with the development of collapse and death [9, 10, 15-17].

The inhalation effect of ricin causes in animals (mice, rabbits, primates) the formation of respiratory distress syndrome with damage to the bronchi and lungs with severe shortness of breath. At high doses, noncardiogenic pulmonary edema and death due to hypoxemia occur within hours. [10, 11, 13, 14, 19]. The pathological picture is characterized by significant vascular permeability, perivascular pulmonary edema, filling of the alveoli with exudate with a high content of pro-inflammatory cytokines and hyaluronidase. In addition, there is a significant violation of microcirculation and thrombus formation. Within a few hours after inhalation of ricin, animals develop an increase in extravascular fluid in the lungs and alveolar edema. Immunochemical studies have shown that inhaled ricin binds to ciliated cells, alveolar macrophages, and alveolar parietal cells of the airways [27], with crude ricin causing greater and more varied disorders $[9$, $10,13,14]$. The inhalation effect of ricin on 
non-human primates has shown that its inhalation toxicity has a dose-dependent preclinical period of 2-24 hours. In the clinical period, animals have shortness of breath, a progressive decrease in motor activity and anorexia. In 6-48 hours after inhalation of ricin, the animals died from pulmonary failure and pulmonary heart disease. The rate of death of animals also depended on the inhaled dose. Pathomorphologically, the dead monkeys revealed purulent-fibrinous pneumonia, the lungs were not collapsed, but heavy, of dense elastic consistency, covered with liquid. The visceral pleura is covered with a fibrin film. There is serous fluid with fibrin filaments in the pleural cavity. Massive haemorrhages and necrotic changes were observed on the surface of the lungs. Morphologically, purulent fibrous alveolitis with infiltration by neutrophils, lymphocytes and macrophages took place in the lung tissue. Terminal bronchioles are necrotic and "swollen" by migration of eosinophils, erythrocytes, macrophages, and deposition of fibrin strands. In several monkeys, adrenocortical necrosis was found.

After oral administration of ricin, the animals had dose-dependent haemorrhagic and necrotic disorders in the gastrointestinal tract, toxic damage to the liver, kidneys, and spleen. Animals die at high doses within 12-48 hours from hepatorenal syndrome. Pathomorphologically there are multiple haemorrhages and foci of necrosis in the gastrointestinal tract, mesentery, liver, kidneys, lymph nodes and ascites.

Acute ricin poisoning in humans, including by castor-oil plant seeds, was quite common in the last century. More than 1000 cases of deliberate and suicidal poisoning were described [928], but in recent decades they have also been recorded. The clinical picture of ricin intoxication is a manifestation of local and resorptive action, which are based on cytotoxic and cytostatic effects, a violation of metabolic processes in cells into which this substance penetrates [9, 10, 11, 28]. The clinical manifestations of intoxication depend primarily on the dose of ricin and the route of administration into the body; its estimated lethal dose for humans when taken orally is approximately $0,3 \mathrm{mg} / \mathrm{kg}$ (about $20 \mathrm{mg}$ ). When a fine aerosol is inhaled, its toxicity is much higher, the minimum inhalation lethal dose of ricin for humans is close to $40 \mathrm{mg} / \mathrm{kg}$. Ricin is not toxic through intact skin [9-16, 23, 24, 27, 28]. Ricin easily penetrates by inhalation through the cells of the alveolar-capillary barrier of the bronchopulmonary system, somewhat less through the mucous membrane of the gastrointestinal tract when administered orally. Once in the blood, the substance is distributed in the body, quickly fixed on the surface of erythrocytes, endothelial cells of various organs and tissues. Within a few hours after eating ricin or castor-oil plant seeds (castor beans), a poisoned person develops nausea, vomiting, abdominal pain, bouts of intestinal colic, then profuse diarrhoea with blood, often bleeding from the anus. These manifestations are joined by anuria, convulsions, pupillary dilation, an increase in body temperature to $40-41{ }^{\circ} \mathrm{C}$, headache, increased thirst, cyanosis of the skin. They are joined by icterus, anuria, vascular collapse, and shock. Death occurs within a few hours at high doses, but more often after 2-4 days [9-16, 27, 28].

The literature describes the murder of the Bulgarian dissident Georgiy Markov in London in 1978. Probably a 1,7 mm bullet, which contained about $500 \mathrm{mg}$ of ricin, was fired into his thigh with an umbrella. Markov almost immediately felt a local pain in his thigh, in the area where the bullet had hit. After 10-15 hours, his temperature rose sharply, nausea and vomiting appeared. On the second day after the shot, he was taken to the hospital in serious condition with a high fever, tachycardia, enlarged painful lymph nodes, and vomiting blood. On the third day, leucocytosis up to $32200 / \mathrm{mm}^{3}$, icterus, anuria, vascular collapse, tachycardia appeared, the ECG revealed a complete atrioventricular blockade. By the end of the third day, Markov died [9, 10, 29].

Ricin poisoning can be suspected based on clinical signs namely nausea, abdominal pain, bloody diarrhoea, disseminated internal vascular coagulation with the formation of hepatocellular, renal, and cardiovascular collapse. Damage due to the action of ricin aerosol can be assumed in the case 1) if after a few hours the patients had haemorrhagic phenomena in the retina, signs of progressive pulmonary pathology i.e. shortness of breath, haemoptysis, detection of bilateral large infiltrates, pleurisy, and increasing pulmonary edema on radiographs; 2) if the pathology in the section due to the action of a fine aerosol is detected; 3 ) if the epidemiology of a point source of a localized lesion is established [9, 10, 25, 30]. 
To confirm ricin intoxication, at least 24 hours after the incident, is possibly by ELISA. The ELISA sensitivity for ricin is $1 \mathrm{ng} / \mathrm{ml}$ when determining the toxin in a buffer solution, bronchial lavage, blood serum and urine [31].

Because of its high toxicity and ease of manufacture, the US Department of War considered ricin as a potential weapon as early as 1918 and named it "compound W". The "W bomb" was developed in Great Britain and the USA and was tested during the Second World War, but it was never officially used $[9,32]$. The authors also report on recent attempts to assassinate US presidents and a senator by sending envelopes containing ricin powder $[9,32,33]$.

The risk of bioterrorism with the use of such a highly toxic substance as ricin remains, and there are still no effective treatments, the toxin acts quickly and irrevocably. Therefore, vaccination of high-risk groups as a preventive measure is an important protective strategy [9, 10, 26-28, 32]. Effective vaccines containing anti-ricin monoclonal antibodies have been developed [9, 10, 25-28, 32-36]. In recent years, considering the powerful cytotoxic and cytostatic effects of ricin, its modified toxin has been used to develop chemotherapeutic agents for the treatment of cancer.

It should be noted that in developed countries, the handling, storage and use of such a highly toxic hazardous substance as ricin is subject to special control.

2. Thallium and its compounds. Thallium (Tl) and its compounds $\left(\mathrm{Tl}^{+}\right)$are still widely used in various industries. Thus, in the electrical industry they are used in the manufacture of selenium rectifiers, calibrated spectral instruments, as well as in the production of electrodeless discharge lamps. In the nuclear industry, $\mathrm{Tl}^{+}$is used as an activator of luminescent alkali halide crystals, in scintillation counters. Tl alloys have high antifriction properties and high corrosion resistance. $\mathrm{Tl}^{+}$is used in geology for growing crystals, and formicmalonic acid $\mathrm{Tl}$ is a part of a special reagent, namely "Clerici solution", which is used in geology to determine the presence of non-ferrous metals [37-41].

In instrument engineering, individual $\mathrm{Tl}^{+}$is used as a source of $\beta$-radiation. $\mathrm{Tl}^{+}$is actively used in the production of optical lenses and other optical elements, as well as new semiconductor materials with varying conductivity properties and in the production of paints and jewellery. Until 1970s-1985s, Tl compounds were widely used in various countries, in particular in Ukraine, in agriculture as rodenticides, insecticides to disinfect grain (seedstock), in dermatology as part of means for hair removal in the treatment of mycoses of the scalp [37-43].

Thallium was first discovered in 1861 . William Crookes, while burning dust in a sulfuric acid industrial plant, noticed a bright green spectral band which quickly disappeared. The new element was named thallium (from the Greek - "Talos" green shoot) [37].

The main compounds of thallium are thallium sulphate, thallium acetate, thallium iodide, thallium bromide, thallium oxide, thallium hydroxide, thallium fluoride, thallium carbonate, thallium malonate, thallium nitrate. Most of the $\mathrm{Tl}$ compounds are classified as highly toxic substances of the 1st class of hazard. Their toxicity increases with increasing solubility in water. Soluble salts of $\mathrm{Tl}$ are absorbed both when taken orally (within 2-3 hours) and when administered parenterally, through intact skin and the broncho-pulmonary system when inhaled. At the same time, highly soluble $\mathrm{Tl}^{+}$salts (sulphate, acetate, carbonate) are absorbed faster in the intestine than less soluble salts (sulphide and iodide). After oral ingestion of thallium sulphate, it can be detected in faeces and urine within one hour. In the early stages, large $\mathrm{Tl}$ concentrations are found in the liver, kidneys, brain, peripheral nerves, heart, and testes [45]. In humans and animals, $\mathrm{Tl}^{+}$is excreted mainly by the kidneys with urine (up to $70 \%$ ) and faeces, as well as with saliva, sweat, tears, and breast milk [46]. The elimination half-life from the human body depends on the $\mathrm{Tl}^{+}$dose, age, and renal function and ranges from 4 to 30 days, but an increased concentration can be observed for several months [45, 46].

The lethal dose for humans is $10-15 \mathrm{mg}$ of soluble Tl salt per $1 \mathrm{~kg}$ of body weight (about 1 $\mathrm{g}$ for a person weighing $70 \mathrm{~kg}$ ). However, death can occur at lower doses $(9-8 \mathrm{mg} / \mathrm{kg}$ ) [52]. Normally, the $\mathrm{Tl}$ content in blood should not exceed $2 \mathrm{mg} / \mathrm{l}$, in urine - from 1,5 to 10 and even $200 \mathrm{mg} / \mathrm{l}$, according to various authors [37-42, 47, 48, 51].

Since the beginning of the 20th century, highly toxic $\mathrm{Tl}^{+}$compounds have been one of the main causes of single and group accidental, intentional, and suicidal acute poisoning, 
which in $15-25 \%$ of cases are fatal to this day [37-43, 44-52]. Due to their widespread use in agriculture, medicine, cosmetology, and other industries, these compounds were quite available. But because of the high toxicity and potential health risks, $\mathrm{Tl}\left(\mathrm{Tl}^{+}\right)$compounds since 1975-1985 were banned or significantly restricted for use in agriculture, as well as in the medical field in most developed countries, including post-Soviet countries, and it contributed to some decline in the number of acute poisoning. However, it should be noted that the production and use of highly toxic $\mathrm{Tl}^{+}$ compounds in agriculture as insecticides, and especially rodenticides, have been preserved in most of the countries of southern Asia [37-39]. In connection with the expansion of the Internet in the 2000s and especially over the past 20 years, the availability of $\mathrm{Tl}$ compounds and the spread of acute $\mathrm{Tl}^{+}$poisoning [37-42, $45,46,52-61,68-71]$ again increased in all countries, including in Ukraine [48, 50]. This became possible due to the placement of advertisements for retail and wholesale trade of $\mathrm{Tl}^{+}$from China and other countries on the Internet. It again increased its availability [48, 50]. In several countries, both single and group cases of intentional (criminal), accidental and suicidal acute poisoning with $\mathrm{Tl}$ compounds has become more frequent [38-42, 45, 48-61, 68-71]. So, A. Livanov and co-authors [61] describe acute oral group severe $\mathrm{Tl}^{+}$poisoning of a criminal nature in Russia in Yaroslavl (14 people), Moscow (8 people), St. Petersburg (5 people). L. Zavaliy et al. [39] describe 44 cases of acute oral poisoning with $\mathrm{Tl}^{+}$at a plant in Taganrog, while admitting a criminal oral route of ingestion of $\mathrm{Tl}^{+}$with drinking water from an office cooler. Accidental and deliberate poisoning with $\mathrm{Tl}^{+}$during the use of narcotic drugs in Iran, especially those containing opium, and which come from Afghanistan, when thallium or lead compounds are added to drugs for weight gain or deliberately, have been described [78, 79].

The increase of the development of both individual and group cases of acute oral and inhalation $\mathrm{Tl}^{+}$poisoning of an accidental and criminal nature in Ukraine in recent years was described by us in previous issues of the journal [48, 50, 64-67]. Attention was focused on modern concepts of the mechanisms of toxic action of $\mathrm{Tl}^{+}$, on clinical performance, on diagnosis of acute poisoning, on dynamics of thallium content in biological media (blood, urine, hair, and nails) of patients with oral and inhalation acute poisoning with thallium compounds, which were under our supervision. It has been shown that in Ukraine in recent years the emergence and development of acute oral poisoning with $\mathrm{Tl}^{+}$, including the severe form, has become more frequent, and an unusual group case of acute inhalation poisoning with thallium sulphate vapor has been recorded.

The most famous case of group oral poisoning with $\mathrm{Tl}^{+}$was a criminal incident in March 1987 in one of the Kyiv schools, where the dishwasher Ivanyutina Tamara, because of personal hostility, decided to poison the cook and added Clerici solution (the most highly toxic thallium compound) to the food left after lunch. This tragic story has been widely covered in the press and on television [64-67], a documentary series "Poisonous School" [67] was shown on one of the TV channels. Unfortunately, later 13 people (schoolchildren and several teachers) came to the canteen and were fed a poisoned lunch. A few hours later, everyone started vomiting, had intense abdominal pain, diarrhoea, chills, fever, pain in the muscles of the extremities. Patients with suspected food intoxication were admitted to the intensive care unit. Symptoms during hospitalization were agitation, facial flushing, fever, nausea, vomiting, intense abdominal pain, diarrhoea, generalized muscle pain, excruciating painful paraesthesia in the hands and feet, convulsions. Two schoolchildren and two teachers died in the first day from growing pulmonary heart disease, the other 9 people continued treatment for food toxic infection in intensive care. On the 4-8th day, intense hair loss began, $\mathrm{Tl}^{+}$poisoning was suspected, the $\mathrm{Tl}^{+}$content in the blood serum of 9 patients ranged from 4660 to $22840 \mathrm{mg} / \mathrm{l}$. Also $\mathrm{Tl}^{+}$poisoning was confirmed during exhumation in the school's dietician, who died two weeks prior to the incident, allegedly of cardiovascular disease. The investigation established that for 11 years Ivanyutina and her sister poisoned 40 people with $\mathrm{Tl}^{+}$, of which 13 poisonings were fatal (she was sentenced to death) [64-67].

In recent years, we have observed 3 cases of severe oral $\mathrm{Tl}^{+}$poisoning, of which 2 are of a criminal nature and 1 because of the accidental use of a thallium sulphate solution, allegedly prepared for deratization. In all three cases, the disease began with abdominal pain, nau- 
sea, vomiting, diarrhoea, fever, intense muscle pain in the extremities, excruciating paraesthesia in the hands and feet, and cramps in the limbs. After 5-8 days, all three victims developed alopecia, mainly in the parieto-occipital region, pyoderma on the face, cracks in the corners of the mouth, hyperkeratosis on hands and feet, weakness in the extremities. After 810 days, dysarthria, ataxia, flaccid paresis of the upper and especially lower extremities, decreased activity of the tendon reflexes of the hands, disappearance of the knee, Achilles and abdominal reflexes appeared. Two of them had a decrease in visual acuity, speech impairment. In all three cases, there was a significant hypotrophy of the muscles of the legs, thighs, shoulders and forearms, dysfunction of the pelvic organs. In two patients, $\mathrm{Tl}$ in urine was determined 10-14 days after the onset of the disease and amounted to 2840 and $2160 \mathrm{mg} / 1$, respectively. In the third patient, $\mathrm{Tl}^{+}$intoxication was suspected only after a month, the $\mathrm{Tl}$ content in the urine during this period was $1425 \mathrm{mg} / \mathrm{l}$. First two patients had neurological symptoms which increased for 1 year and then stabilized with the preservation of encephalomyelopolyradiculoneuropathy with weakness in the arms and flaccid paresis of the lower extremities, with severe ataxia and the ability to move only in a wheelchair during 3 years of monitoring. Complex therapy with the inclusion of the antidote Ferrocin helped to reduce the $\mathrm{Tl}$ content in urine to $100-120$ $\mathrm{mg} / \mathrm{l}$. Within a month, no regression of neurological disorders was observed; decreased vision, depression, cognitive impairment progressed; and pelvic organ dysfunction persisted. After severe alopecia in 4-6 months in all three cases, thick hair grew. In the third patient, neurological symptoms increased up to 6-8 months, then after a long rehabilitation they slightly decreased. At control after 1-year, flaccid paresis of the lower extremities, ataxia remained, but the patient began to move slowly with the help of crutches. All three patients were assigned to 1 group of disability. During electroneuromyography, signs of significant motor-sensory polyneuropathy of an axonal nature were found. It should be noted that the first two patients were diagnosed with thallium toxicosis after 10-14 days, and timely antidote therapy with ferrocin was performed, a decrease in the level of $\mathrm{Tl}^{+}$in the urine was revealed, but there was practically no regres- sion of neurological symptoms. In the third patient, thallium toxicosis was established only a month later, and before that he was treated in various clinics in Kiev with a diagnosis of polyneuropathy of unknown aetiology with the appointment of hormones, antibiotics, and plasmapheresis (№ 5). The antidote ferrocin was prescribed to him a month later, when $\mathrm{Tl}^{+}$ in urine was $1425 \mathrm{mg} / \mathrm{l}$; after treatment with the inclusion of ferrocin, $\mathrm{Tl}^{+}$in urine dropped to $116 \mathrm{mg} / \mathrm{l}$, after a year the patient began to move with the help of crutches. If after a month the level of $\mathrm{Tl}^{+}$in urine was $1425 \mathrm{mg} / \mathrm{l}$, then it can be assumed that in the acute period its level was significantly higher. In addition, he received specific therapy a month later, but the regression of neurological disorders was more noticeable compared to the first two cases.

Three cases of the development of acute inhalation poisoning with $\mathrm{Tl}^{+}$vapors in car drivers are of particular interest. Their car was being repaired in the courtyard of a private person who had several dogs that disturbed neighbours. Probably one of them decided to kill the dogs and threw the poisoned porridge over the fence. The porridge got into the car and through the open hood on the engine. The owner wiped the outside of the car, and his 23-year-old son started working on it. After 1,5-2 days, he developed an intense burning sensation in the throat, along the trachea, behind the sternum, in the diaphragm, shortness of breath, intense pain in the muscles of the extremities, periarticular tissues, painful paraesthesia in the fingers and toes, abdominal pain, severe weakness in the legs. At first, the patient was treated with suspicion of neuroinfection, after the onset of alopecia, acute $\mathrm{Tl}^{+}$ poisoning was laboratory confirmed and the victim was transferred to an emergency hospital. With an increase in pulmonary heart disease, the patient died at the end of the summer of 2018 with a diagnosis of acute $\mathrm{Tl}^{+}$poisoning, however, the relationship between the development of intoxication and driving a car was not established. After the death of the young man, his 42-year-old father and 48year-old partner periodically began to work on this car. In November 2018, with the onset of cold weather, they began to turn on the air conditioner to heat the car interior, after which they felt a burning sensation in the throat, along the trachea, behind the sternum, then 
both developed intense muscle pain, paraesthesia in the fingers and toes, and weakness in the legs, alopecia began to develop.

The father of the deceased young man was in the autumn of 2018 admitted to the toxicology department of the emergency hospital in Kyiv, where he was treated for 1,5 months with a diagnosis of acute poisoning with $\mathrm{Tl}^{+}$salts, second-third degree encephalopolyradiculoneuropathy syndrome, first-second degree toxic hepatitis. A week later, with similar complaints, his partner for work on this car entered the same department, who was treated for 20 days with a diagnosis of acute poisoning with thallium salts, second-degree polyradiculoneuropathy syndrome, first-second degree toxic hepatitis. In both patients, when examined in our Scientific Centre, the $\mathrm{Tl}^{+}$level in the hair was more than 10 times higher than the norm, and in the urine $-320-280 \mathrm{mg} / \mathrm{l}$. After complex detoxification therapy with haemodialysis, a course of antidote therapy with ferrocin, nootropics, analgesics, anticonvulsants, antioxidants, B vitamins, PP vitamin, and the patients' condition improved, there was a significant regression of neurological disorders, chest pains and muscle pains disappeared, hair loss stopped. The chemical and toxicological assessment of the $\mathrm{Tl}^{+}$content in the hair and nails of patients, carried out in our Scientific Centre 2,5 months after acute poisoning, found the following $\mathrm{Tl}^{+}$content in one patient, namely in the hair $-800 \mathrm{mg} / \mathrm{kg}$, in the nails $-2230 \mathrm{mg} / \mathrm{kg}$, in the skin epithelium $190 \mathrm{mg} / \mathrm{kg}$. In another patient with more significant neurological disorders, the $\mathrm{Tl}^{+}$level was higher, namely in the hair $-3980 \mathrm{mg} / \mathrm{kg}$, in the nails $-9080 \mathrm{mg} / \mathrm{kg}$, in the skin epithelium $-620 \mathrm{mg} / \mathrm{kg}$, which indicates a certain dependence of the severity of clinical manifestations on the content of $\mathrm{Tl}^{+}$in biological media, mainly in urine and nails. It should be noted that 2,5 months after the poisoning, high levels of $\mathrm{Tl}^{+}$were in the hair and especially in the nails of the patients. A year later, peripheral polyneuropathy, mild ataxia, tremor of the fingers of outstretched arms, hyporeflexia, and depression persisted.

Unfortunately, the chemical and toxicological assessment of the surfaces of the car, on which all three victims worked, was carried out at the Scientific Centre only six months after the first of three cases of acute $\mathrm{Tl}^{+}$poisoning occurred. Extraction was carried out with $5 \%$
$\mathrm{HCl}$ sections of artificial leather from the front seats and floor mats. In 3 samples taken from the seats six months later, rather high concentrations of $\mathrm{Tl}^{+}$were revealed, up to $68060 \mathrm{mg}$ per $30 \mathrm{ml}$ of extract (or $2269 \mathrm{mg} / \mathrm{ml}$ ). $\mathrm{Tl}^{+}$concentrations in the extracts were slightly lower in samples from carpets lying on the floor of the cabin. Considering the pollution of the interior of the car with $\mathrm{Tl}^{+}$, which apparently was more significant six months ago, acute poisoning with $\mathrm{Tl}^{+}$probably arose by inhalation. In addition the clinical manifestations in the last two patients appeared already at the onset of cold weather, in early November, when the car windows were closed, and interior heating was switched on. It should be noted that the Research Centre conducted a study of the $\mathrm{Tl}^{+}$content in bio-samples of an exhumed corpse of a man who died in 2019 from a neurological pathology of unclear aetiology (at the insistence of relatives, poisoning was suspected). In biopsies of the skin area of an exhumed corpse, the $\mathrm{Tl}^{+}$level reached $8000 \mathrm{mg} / \mathrm{kg}$, and in cut nails $9000 \mathrm{mg} / \mathrm{kg}$, which made it possible to establish that the cause of his death was also $\mathrm{Tl}^{+}$poisoning.

The described cases of $\mathrm{Tl}^{+}$intoxication indicate that the availability of purchasing its compounds on the Internet contributes to the growth of acute poisoning among the population, in addition, it cannot be ruled out that in many cases patients died before an accurate diagnosis was established.

Group $\mathrm{Tl}^{+}$poisoning of a criminal nature has also become more frequent in Japan [72, $73,77]$, China $[58,62,64,75,76]$ and in many other countries [40-46, 52, 55, 58-60]. Several works describe terrorist incidents of acute group poisoning associated with the consumption of food contaminated with $\mathrm{Tl}^{+}$, for example, of alcohol in Iraq [59], of sweets in Syria [60].

The mechanism of the toxic action of $\mathrm{Tl}^{+}$ was summarized by us in the previous issues of the journal $[48,50]$. The toxicity of $\mathrm{Tl}^{+}$is based on its ionic similarity to potassium, what is more thallium compounds are almost 10 times more active than potassium, therefore they replace potassium and compete with it for a place in mitochondrial and other cell membranes, numerous enzymes; they interact with $\mathrm{Na}^{+} / \mathrm{K}^{+}$-adenosine triphosphatase, causing energy deficiency and activation of lipid peroxidation. These processes are facilitated by 
the blockade of SH-groups, an increase in the concentration of intracellular calcium, an increase in the glutamatergic component in $\mathrm{Tl}^{+}$-induced toxicity in the structures of the brain, as well as an increase in the excitability of nerve cells with the formation of degenerative disorders in them.

At the same time, riboflavin insufficiency is formed, which, along with the high affinity of $\mathrm{Tl}^{+}$with melanin, disrupts the process of epidermal keratinization, suppresses cell proliferation, especially of follicular melanocytes, and causes the development of one of the syndromes specific for $\mathrm{Tl}^{+}$poisoning, namely alopecia.

The clinical manifestations of $\mathrm{Tl}^{+}$poisoning in the first hours and days are quite nonspecific, however, a combination of several symptoms and syndromes, as well as the sequence of their development, should make the doctor suspect acute poisoning with this dangerous substance and begin a chemical and toxicological examination. The sequence of development of the main symptoms of $\mathrm{Tl}^{+}$intoxication was substantiated by us in the previous issues of the journal $[48,50]$ :

- during the first hours of $\mathrm{Tl}^{+}$poisoning, gastrointestinal disorders are most often observed, accompanied by intense pain in the abdomen, often intestinal colic, as with lead intoxication, nausea, vomiting, diarrhoea, anorexia, imitating the picture of food poisoning, less often constipation, bloating. However, it should be noted that these gastrointestinal disorders precede or are combined with excruciating paraesthesia in the fingers and toes, intense bursting pains in the soles of the feet, convulsions, increasing tremor, and at high doses precede or are combined with mental disorders, sleep disturbances, headache, disorders of cranial nerves with a decrease in corneal and pharyngeal reflexes, as well as with an increase in body temperature to $37,6-38^{\circ} \mathrm{C}$; in addition, in the first hours, especially when exposed to large doses, the urine acquires a greenish colour;

- for 2-10 days, neurological disorders progress, tremor, ataxia increase; pain in the extremities increases, especially in the area of the calf muscles and muscles of the inner thigh, acquiring signs of neuropathic; muscle atrophy appears, mainly in the area of the upper shoulder girdle, legs and thighs; dysfunction of cranial nerves increases, paralysis of the facial nerve, ptosis, diplopia, retrobulbar neuritis, visual impairment are possible. If in the first 2-3 days tendon reflexes persist, then later they disappear, at high doses flaccid paralysis, tetraparesis, dysfunction of the pelvic organs appear, as well as dysfunctions of the heart and kidneys join, often death occurs from pulmonary heart disease;

- after 7-14 days, the surviving patients develop alopecia, mainly in the parietal and temporal areas of the head (Fig. 2), the haircovering also disappears in the axillary and pubic areas, the medial and lateral third of the eyebrows; peeling of the skin, hyperkeratosis of the palms and soles, cracks in the corners of the mouth, brown pigmentation, deposition of dark pigment on the skin around the hair follicles, pyoderma (pustular rashes and small

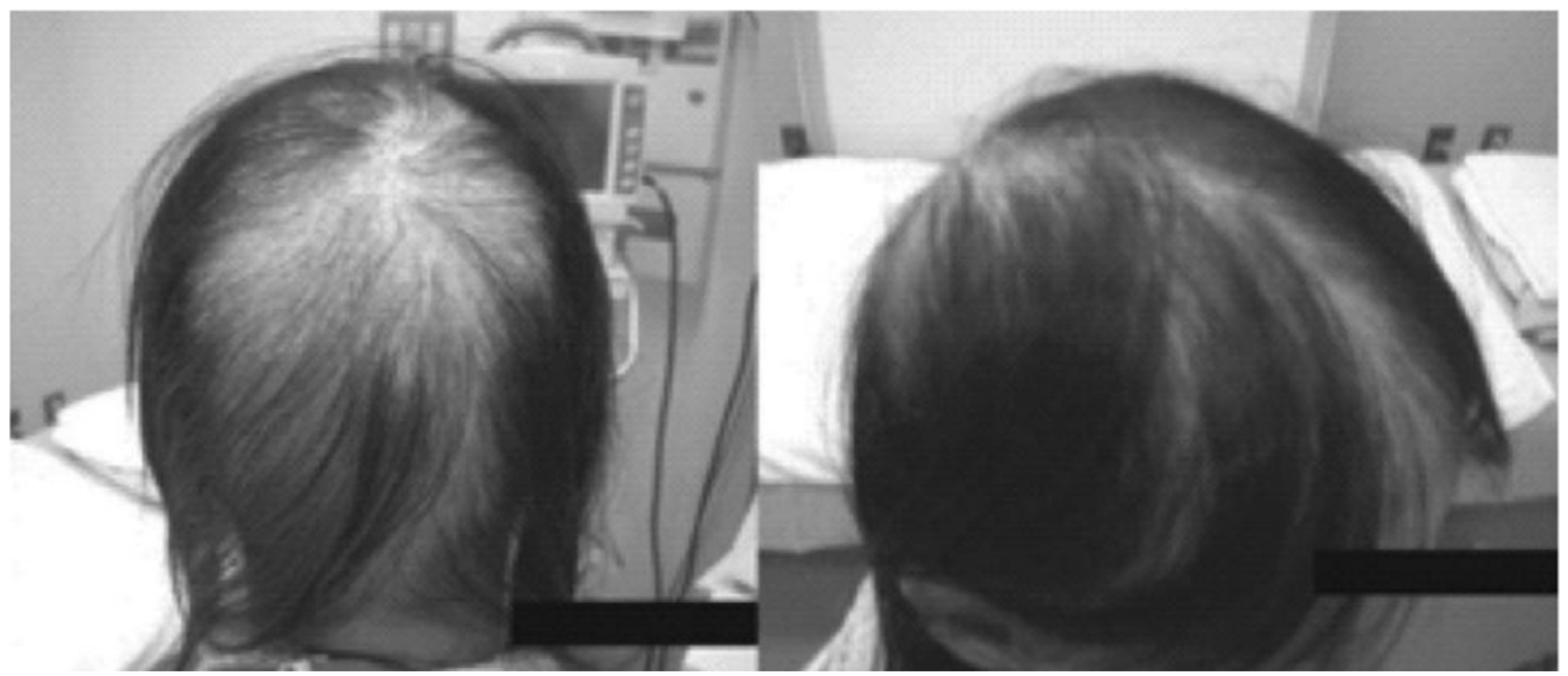

Fig. 2. Alopecia of the scalp in a patient with acute thallium poisoning (Yumoto $T$ et al, 2017) [69] 
boils, especially on the face, less often on the chest and back) develop; the growth of nails sharply slows down; they fade, turn yellow, horizontal tortuosity appears with white transverse stripes (Mees stripes, Fig. 3).

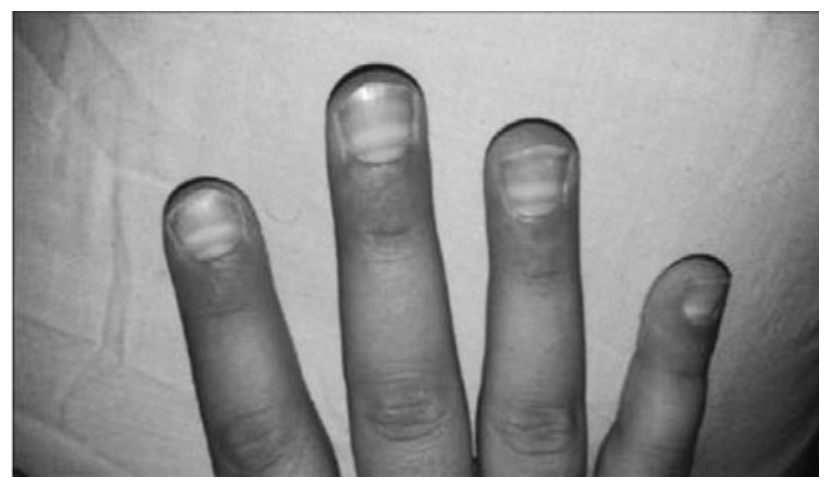

Fig. 3. Lesion of nails with the formation of transverse Mees stripes in a patient with acute thallium poisoning (Almassri I, Sekkarie M, 2018) [60]

Unfortunately, in most of the described cases of acute $\mathrm{Tl}^{+}$poisoning, the diagnosis is made late, most often after 1-2 weeks, when alopecia appears, often after 1,5-2 months. Because of this, the prescription of the antidote ferrocin (Prussian blue) and extracorporeal detoxification are postponed, as a result, severe disorders of central and peripheral nervous system are formed with the development of paresis and paralysis, which leads to disability. This paper does not consider a case of chemical exogenous intoxication in Chernivtsi in 1988, the most likely cause of which could be the ingestion of thallium into the body by its inhalation in an ultra-micro-dispersed (nano-) state.

Considering the presented literature data and the results of our own studies of the high toxicity of thallium compounds, their availability via the Internet, untimely establishment of an accurate diagnosis and frequent disability or death in the development of acute poisoning, the need for special control over the traffic of $\mathrm{Tl}^{+}$, its storage, use and disposal is justified.

3. Cholinesterase inhibitors. Currently, organophosphorus compounds (OPs) are widely used all over the world in the chemical industry as solvents and plasticizers, in agriculture as insecticides and acaricides, in the pharmaceutical industry as medicines, in the military industry as chemical warfare agents. In the last two decades, in many countries of the world, the widespread use of OPs has become one of the causes of acute and chronic poison- ing (occupational, domestic, suicidal, and criminal) [80-87]. According to the WHO, 3 million people are registered annually in the world who has suffered OP poisoning, while for 200,000 people the poisoning had fatal consequences [88, 89]. In addition, the growth in the activity of international terrorism increases the risk of using both known organophosphate toxic substances and new compounds with an unknown chemical structure, which requires emergency medical care, accurate diagnosis, effective treatment, and prediction of the consequences of intoxication, as well as scientific development of strategies for effective health protection of people in the case of the use of OPs [90-93].

The scale of the threat of terrorism is evidenced by cases of poisoning in the cities of Matsumoto (1994), Tokyo (1995), Amman (1997), New York (2001), Moscow (1997, 2002, 2003), etc. In recent decades, mass terrorism has grown into international terrorism. Transnational terrorist groups, in particular Aum Shinrikyo, Al-Qaeda and others, which have the ability to use any methods of mass terrorism to destroy people, animals, vegetation, material values [94], as well as terrorist acts of individual criminal elements or intelligence services, in particular in Salisbury (2018) and Tyumen (2020), with unknown highly toxic OPs, such as Novichok, are widely known.

Among organophosphate substances that can quickly cause acute poisoning with a lethal outcome, an important place is occupied by cholinesterase blockers, including chemical warfare agents such as sarin, soman, tabun, $\mathrm{V}$-gases, which can fall into the hands of terrorists by seizing their storage facilities or damage to storage areas due to hostilities, or while disposing. In addition, the use of chemicals intended for other purposes (industrial chemicals, pesticides, etc.), which are more available, is not excluded. The use of modern knowledge, training, technical support, and financial capabilities of a subject who acts as a terrorist does not exclude the synthesis of toxic substances in clandestine laboratories [94, 95].

Substances with anticholinesterase action, in addition to OPs, include substances of very different chemical structures and with very different biological properties. More than half of anticholinesterase substances (depending on the functional chemical group that determines their anticholinesterase properties) are divided 
into 4 main groups: quaternary ammonium compounds, carbamic acid esters (urethane and carbamates), organophosphates and others. Other substances, such as narcotics, strychnine, curare-mimetic and locally irritating substances, nitrogen mustard gas, and others, can also have a significant anticholinesterase effect. However, they exert this effect only in relatively high concentrations, and therefore the ability to suppress the activity of cholinesterase is not decisive for the mechanisms of biological action [96-99].

Most anticholinesterase compounds have high physiological activity, and therefore many of them (eserine, neostigmine, phosphacol, armine, pyridostigmine, etc.) are used in medical practice for the treatment of diseases, and some are in service as highly toxic warfare toxic neuroparalytic substances (tabun, sarin, soman, V-gases). Currently, organophosphate pesticides and carbamic acid derivatives make up a significant part of the range of compounds that are widely used in agriculture, forestry, and animal husbandry as active insecticides and acaricides [98] and therefore are widely available to the population.

The mechanism of reactions of OPs with cholinesterase, cholinergic receptors (CR), the dependence of their effect on the body on the structure are described in detail in many works by Aldridg W.N. (1950, 1981), Brain A. (1964, 1976), Fukuto T. (1972), Casida J.E. (1973), Golikov S.N. (1970, 1972, 1973), Eto M. (1974), Narahashi T. (1976) and others, and are summarized in publications [98, 100-104]. It has been proven that during the interaction of OP with cholinesterase, the esterase centre is strongly bound to the phosphoric acid residue, which leads to the formation of a phosphorylated enzyme, extremely resistant to hydrolysis, capable of reacting with acetylcholine (ACh) molecules due to the loss of its main catalytic function. As a result of cholinesterase inactivation, acetylcholine is accumulated in cholinergic synapses, hyperstimulation of receptors, impaired passage, and blockade of nerve impulses through the synaptic membrane appear, that leads to disruption of the activity of the central and peripheral nervous system, other vital organs, and subsequently to death. Inhibition of cholinesterase is the main mechanism of the toxic action of OPs. However, since cholinesterase and cholinergic receptors have much in common in their structure, so their interaction not only with the enzyme, but also with cholinergic receptors may have a certain value in the mechanism of action of anticholinesterase compounds. At the same time, some OPs (phosphacol, diisopropyl fluorophosphate (DFP), parathion, armine, etc.) can exhibit both stimulation and blocking effects on cholinergic receptors [98, 105-107].

There are substances among OPs with varying degrees of toxicity. According to toxicity, OPs are divided into:

1. Potent toxic substances $\left(\mathrm{LD}_{50}-10-\right.$ $50 \mathrm{mg} / \mathrm{kg}$ ) such as thiophos, mercaptophos, O-methyl-O-ethyl-O-(4-nitrophenyl)thiophosphate.

2. Highly toxic substances $\left(\mathrm{LD}_{50}-50-\right.$ $200 \mathrm{mg} / \mathrm{kg}$ ) - demeton-S-methyl, O,O-dimethylS-(N-methylcarbamido-methyl)dithiophosphate, DDVP, Bazudin, antio, cidial, O,Odimethyl-S-phthalimidomethyldithiophosphate, benzofosfatum.

3. Moderately toxic substances $\left(\mathrm{LD}_{50}-\right.$ 200-1000 mg/kg) - metrifonate, O,O-dimethyl-O-(3-methyl-4-nitrophenyl)thiophosphate, O,O-dimethyl-S-(1,2-dicarbeth-oxyethyl) dithiophosphate, trichlorometaphos-3, sayfos.

4. Low-toxic substances $\left(\mathrm{LD}_{50}-\right.$ more than $1000 \mathrm{mg} / \mathrm{kg}$ ) - vinyl phosphate, bromophos, abate, cyanox, valekson, demufos.

A separate group includes chemical warfare agents $\left(\mathrm{LD}_{50}\right.$ less than $\left.10 \mathrm{mg} / \mathrm{kg}\right)$ - sarin, soman, VX [93, 108-110].

Depending on the dose received in the body, signs of OPs intoxication can develop immediately or after several hours. For more lipophilic compounds that require metabolic activation, symptoms of intoxication develop slowly and may persist for several days. Depending on the structure of the substance, the rate and direction of metabolism, the severity of certain disorders on the part of the central nervous system may change.

In acute intoxication with OPs, the symptoms of cholinergic crisis include muscarinic effects (nausea, vomiting, diarrhoea, convulsions, urinary incontinence, miosis, bronchorrhea, bronchoconstriction, respiratory distress, salivation and lacrimation, hypotension, bradycardia, arrhythmia); nicotine effects (muscle weakness, tremor, paresis of the diaphragm, hypertension, tachycardia, mydriasis) changes in the central nervous system (anxiety, agitation, headache, dizziness, ataxia, memory loss, convulsions, coma). 
The first signs of cholinergic symptoms appear when the activity of acetylcholinesterase in the blood decreases by $50 \%$, suppression of the enzyme activity by $75 \%$ leads to a severe degree of intoxication and is an indicator of danger, requiring urgent measures to eliminate the effect of the substance [87, 98].

A dose-response relationship is common in the action of many OPs, both in acute and chronic exposure. With an increase in the dose of the administered substance, the effect is enhanced regardless of the route of entry into the body. The severity of inhibition with the administration of the same doses depends on the species and individual sensitivity of the organism. Substances with a high anticholinesterase effect in vitro exhibit toxic effects in the first hours after administration of the substance. For substances with less significant anticholinesterase properties in vitro, as well as substances that require preliminary activation (thionophosphates), toxic effects and anticholinesterase effects appear at later date.

Since OPs selectively block cholinesterase in all cholinergic structures ( $\mathrm{M}$ and $\mathrm{H}$-cholinergic systems), almost all physiological systems and organs can be involved in the pathological process. At the same time, changes in the activity of the central and peripheral nervous systems, as well as, consequently, impaired respiration and cardiac activity have a decisive influence on the consequences of poisoning.

It should be noted that changes in higher nervous activity may be one of the early signs of the effect of OPs on the body. Poisons such as sarin, soman, dichlorvos, parathion and others, when administered even in small doses from 0,1 to $0,3 \mathrm{LD}_{50}$, affect the regularity and reproduction of involuntary innate reactions (perception of auditory and visual stimuli, water, and food consumption) [111]. The development of clonic-tonic seizures in acute poisoning with OPs (phosphacol, diisopropyl fluorophosphate (DFP), sarin, tabun, parathion, DDVP, hostakvik and others) may indicate the involvement of the spinal cord in the pathological process. It should also be noted that OPs with a significant anticholinesterase effect $\left(\right.$ I50 $\left.=1 \times 10^{-7}-1 \times 10^{-9} \mathrm{M}\right)$ are strong miotics. Miosis can serve as a criterion for the severity of the patient's condition. In severe poisoning, "pinpoint" pupils persist for a long time, there is no reaction to light, and vertical and horizontal nystagmus is noted [108].

Noncholinergic mechanisms are manifested mainly upon repeated intakes of small doses of agents capable of causing significant cholinergic reactions, and usually play a large role in the action of less toxic OPs, which include many pesticides [98].

Several OPs of various structures, namely phosphates, phosphonates, amidophosphates, can cause a long-term neurotoxic action. This effect manifests itself after a latent period (14-21 days, and sometimes several years after acute poisoning) and is characterized by the occurrence of ataxia, muscle weakness, paresis and paralysis of the extremities, demyelination of the fibres of the pathways of the spinal cord and peripheral nerves. The classic OPs that have a long-term neurotoxic action are tricresyl phosphate (TOCP) and leptophos. Currently, more than 40,000 cases of paresis and paralysis in humans have been described due to the action of OPs (TOCP, mipafox, leptophos, chlorpyrifos, metrifonate, etc.) [112-116]. The mechanism of long-term neurotoxic action causes by OPs is not fully understood. Phosphorylation of a protein that belongs to carboxylesterases and is called neurotoxic esterase (EC 3.1.1.5, NTE) is an important pathogenetic link in disorders [112, 113, 117, 118]. Remote neuropathies arise only in the case of the influence of such OPs, which suppress NTE by 70$80 \%$, and the development of long-term neurotoxic action is associated not only with suppression of NTE, but also with its subsequent "aging" [119]. Recently, studies of the structure of the NTE and its functional role have continued. Some signs of homology of NTE with $\mathrm{Ca}$-independent phospholipase $\mathrm{A}$ was found. It has been shown that for OPs, which cause long-term neurotoxic action, inhibition of NTEs is accompanied by disruption of membrane phospholipid homeostasis, which leads to damage to axonal transport [118]. The role of NTEs in the hydrolysis of lysophospatidylcholine and the participation of lipases in the detoxification of some OPs is discussed [120].

It is likely that the chemical agent Novichok, which in recent years has been used as a means of poisoning people, can also be attributed to the substances that produce long-term neurotoxic action.

According to the data available on the Internet, the poisonous substance "Novichok" 
(https://m.pikabu.ru/story/otravlyayushchee veshchestvo_quotnovichokquot_5778177) in its structure and mechanism of action refers to organophosphates of nerve-paralytic action, and in terms of toxicity is 5-8 times higher than a well-known chemical warfare agent VX. According to the mechanism of action, a series of toxic substances called "Novichok" are irreversible inhibitors of acetylcholinesterase. Little is known about the symptoms of poisoning with "Novichok", it is believed that the clinical picture of poisoning is the same as in the case of damage caused by conventional nerve agent warfare agents such as sarin, soman, VX, etc. However, there are differences, which lie in the fact that the damage caused by these substances was virtually incurable. People who at one time were exposed to this substance became disabled, that is, disabled due to the development of paralysis and damage to internal organs. These phenomena appear delayed after poisoning with certain organophosphates, they are characteristic of long-term neurotoxic action, unfortunately, they are practically not treated by known means.

Based on the mechanism of long-term neurotoxic action of OPs, along with generally recognized methods of treatment and antidote therapy (reactivators of peripheral and central action) $[91,108]$, in the early stages of poisoning, it is advisable to use hemocarboperfusion and immunosuppressants to prevent complications and the occurrence of paresis and paralysis [121-124].

Considering the high toxicity, great prevalence and availability of OPs, there is a high risk of using them by criminals to poison people, animals, and damage the environment. In this regard, it is necessary to increase the responsibility of those involved in the storage, use, transportation, and disposal of these hazardous substances. Such highly toxic substances as O,O-dimethyl-O-(3-methyl-4nitrophenyl)thiophosphate, metaphos, thiophos, demeton-S-methyl, O-methyl-O-ethylO-(4-nitrophenyl)thiophosphate, octamethyltetramide pyrophosphate, cresyl phosphate, and chemical warfare agents require especially strict control.

Considering the severity of injuries in acute intoxication, high disability, the possibility of fatal cases, it is necessary to improve an integrated approach to the rapid and reliable identification of toxic substances, treatment of acute poisoning, as well as to develop a strategy for multi-level protection of the population and environmental objects if OPs are used for purposes other than intended. The preparation of the medical service for a quick response to terrorist acts with the use of toxic substances, diagnostics, evacuation, and first aid is of particular relevance.

\section{REFERENCES}

1. Proekt Zakonu Ukrainy «Pro khimichnu bezpeku» ta proekty tekhnichnykh rehlamentiv yak pidzakonni akty. Multymediini materialy. URL: https://mepr.gov.ua/news/ 36207.html.

2. Azarov DS, Hryshchuk VK, Savchenko AV ta in. Naukovopraktychnyi komentar Kryminalnoho kodeksu Ukrainy. Dzhuzha OM, Savchenko AV, Cherniei VV, redaktory. 2-he vyd., pererob. i dopov. Kyiv: Yurinkom Inter; 2018, 1104 s.

3. Maksymchuk IM. Otruini rechovyny yak element kryminalistychnoi kharakterystyky okremykh kryminalnykh pravoporushen. Naukovyi visnyk publichnoho ta pryvatnoho prava. Zbirnyk naukovykh prats. K.: Naukovo-doslidnyi instytut publichnoho prava; 2019; 4(1): $32 \mathrm{~s}$.

4. Pro implementatsiiu Uhody pro asotsiatsiiu mizh Ukrainoiu, $\mathrm{z}$ odniiei storony, ta Yevropeiskym Soiuzom, Yevropeiskym Spivtovarystvom z atomnoi enerhii i yikhnimy derzhavamy-chlenamy, $\mathrm{z}$ inshoi storony: Rozporiadzhennia Kabinetu Ministriv Ukrainy vid 17.09.2014 № 847-r. URL: https://zakon5.rada.gov.ua/ laws/show/847-2014.

5. Pro vykonannia Uhody pro asotsiatsiiu mizh Ukrainoiu, z odniiei storony, ta Yevropeiskym Soiuzom, Yevropeiskym spivtovarystvom $\mathrm{z}$ atomnoi enerhii $\mathrm{i}$ yikhnimy derzhavamy-chlenamy, z inshoi storony: Rozporiadzhennia Kabinetu Ministriv Ukrainy vid 25.10.2017 № 1106. URL: https://zakon.rada.gov.ua/laws/show/1106-2017.

6. Pro ratyfikatsiiu Uhody pro asotsiatsiiu mizh Ukrainoiu, z odniiei storony, ta Yevropeiskym Soiuzom, Yevropeiskym spivtovarystvom $\mathrm{z}$ atomnoi enerhii i yikhnimy derzhavamy-chlenamy, $\mathrm{z}$ inshoi storony: Zakon Ukrainy vid 16.09.2014 № 1678-VII. URL: https://zakon.rada.gov.ua/ laws/ show/1678-18.

7. Pro vyznannia takymy, shcho vtratyly chynnist, deiakykh postanov Kabinetu Ministriv Ukrainy: Postanova Kabinetu Ministriv Ukrainy vid 03.09.2014 № 405. URL: https://zakon.rada.gov.ua/ laws/show/405-2014.

8. Pro zatverdzhennia Poriadku oderzhannia dozvolu na vyrobnytstvo, zberihannia, transportuvannia, vykorystannia, zakhoronennia, znyshchennia ta utylizatsiiu otruinykh rechovyn, u tomu chysli produktiv biotekhnolohii ta inshykh biolohichnykh ahentiv: Postanova Kabinetu Ministriv Ukrainy vid 20.06.1995 № 440. URL: https://zakon.rada.gov.ua/laws/show/440.

9. Moshiri M, Hamid F, Etemad L. Ricin Toxicity: Clinical and Molecular Aspects. Reports of Biochemistry \& Molecular Biology. 2016; 4(2): 60-5. 
10. Suponiczkij MV. Raspoznavanie porazhenij riczinom. Prikladnaya toksikologiya. 2013; 9(1): 44-9.

11. Bigalke H, Rummel A. Medical aspects of toxin weapons. Toxicol. 2005; 214: 210-20.

12. Audi J, Belson M, Patel M, et al. Ricin poisoning. A comprehensive review. JAMA. 2005; 294(18): 2343-3251.

13. Griffith GD, Phillips GJ, Holley J. Inhalation toxicology of ricin preparations: animal models, prophylactic and therapeutic approaches to protection. Inhal. Toxicol. 2007; 19: 873-87.

14. Wannemacher RW, Anderson JB, Inhalation ricin aerosol procedures, toxicology and therapy. Inhal. Toxicol. 2006; 42: 973-80.

15. Lord MJ, Jolliffe NA, Marsden CJ, et al. Ricin Mechanisms of cytotoxicity. Toxicol. Rev. 2003; 22: 53-64.

16. Sehgal P, Khan M, Kumar O, Vijayaraghavan R. Purification, characterization and toxicity profile of ricin isoforms from castor beans. Food and chemical toxicology: an international journal published for the British Industrial Biological Research Association. 2010; 48(11): 3171-6.

17. Bradberry S. Ricin and abrin. Medicine. 2012; 40(2): 80-1.

18. Rana M, Dhamija H, Prashar B, Sharma S. Ricinus communis L. International Journal of Pharm Tech Research. 2012; 4(4): 1706-11.

19. Wilhelmsen CL, Pitt ML. Lesions of acute inhaled lethal ricin intoxication in rhesus monkeys. Veterinary pathology. 1996; 33(3): 296-302.

20. Christiansen VJ, Hsu CH, Dormer KJ, Robinson CP. The cardiovascular effects of ricin in rabbits. Pharmacology \& toxicology. 1994; 74(3): 148-52.

21. Coopman V, De Leeuw M, Cordonnier J, Jacobs W. Suicidal death after injection of a castor bean extract (Ricinus communis L.). Forensic Sci Int. 2009; 189(1-3): 13-20.

22. Targosz D, Winnik L, Szkolnicka B. Suicidal poisoning with castor bean (Ricinus communis) extract injected subcutaneously - case report. J. Toxicol Clin Toxicol. 2002; 40: 398

23. Doan LG. Ricin mechanism of toxicity, clinical manifestations, and vaccine development. A review. J. Toxicol Clin Toxicol. 2004; 42(2): 201-8.

24. Bradberry SM, Dickers KJ, Rice P, Griffits GD, Vale JA. Ricin poisoning. Toxicological reviews. 2003; 22(1): 65-70.

25. Balali-Mood M, Moshiri M. Problems of Clinical Diagnosis and Management of a Deliberate Biological Born Disease. J Bioterror Biodef. 2015; 6: 113.

26. Antonov NS. Khimicheskoe oruzhie na rubezhe dvukh stoletij. M.: AlO Izdatel'skaya gruppa «Progress»; 1994.

27. Franz D, Jaax N. Ricin toxin. Medical aspects of chemical and Biological Warfare. Washington; 1997. 631-642.

28. Bova AA, Gorokhov SS. Voennaya toksikologiya i toksikologiya e`kstremal’ny`kh situaczij. Minsk; 2005. 224240.

29. Crompton R, Gall D. Georgi Markov - death in a pellet. The Medico-legal journal. 1980; 48(2): 51-62.

30. Worbs S, Kohler K, Pauly D, Avondet MA, Schaer M, Dorner $\mathrm{MB}$, et al. Ricinus communis Intoxications in Human and and Veterinary Medicine-A Summary of Real Cases. Toxins (Basel). 2011; 3(10): 1332-72.

31. Johnson RC, Lemire SW, Woolfitt AR, Ospina M, Preston $\mathrm{KP}$, Olson CT, et al. Quantification of ricinine in rat and human urine: a biomarker for ricin exposure. J Anal Toxicol. 2005; 29(3): 149-55.

32. Stewart CC. Weapons of Mass Casualties and Terrorism Response Handbook. London: Jones \& Bartlett; 2005.
33. Zhao Z, Worthylake D, LeCour L, Jr., Maresh GA, Pincus $\mathrm{SH}$. Crystal structure and computational modeling of the fab fragment from a protective antiricin monoclonal antibody. PloS one 2012; 7(12): e52613.

34. Moshiri M, Etemad L, Balali-Mood M. The Biowarfare Agent Ricin. Biological Toxins and Bioterrorism Series: Toxinology, Vol 1 Springer; 2014. P. 43-59.

35. Wu F, Fan S, Martiniuk F, Pincus S, Muller S, Kohler H, et al. Protective effects of anti-ricin A-chain antibodies delivered intracellularly against ricin-induced cytotoxicity. World journal of biological chemistry. 2010; 1(5): 188-95.

36. Pincus SH, Smallshaw JE, Song K, Berry J, Vitetta ES. Passive and active vaccination strategies to prevent ricin poisoning. Toxins. 2011; 3(9): 1163-84.

37. Toxicological review of thallium and compounds. U.S. Environmental Protection Agency. Washington. D.C. 2009. EPA/635/R-08/001F.www.epa.gov/iris.

38. Gresham C, Vearrier D. Thallium Toxicity. Medscape. com. 2018 Feb. 19.

39. Zavalij LB, Petrikov SS, Simonova AYu, Poczkhveriya MM, Ostapenko YuN. Kharakteristika nevrologicheskikh rasstrojstv u paczientov s ostry'm otravleniem talliem. Consilium Medicum. 2019; 21(2): 24-30.

40. Osorio-Rico L, Santamaria A, Galván-Arzate S. Thallium Toxicity: General Issues, Neurological Symptoms, and Neurotoxic Mechanisms. Adv Neurobiol. 2017; 18: 345353. doi: 10.1007/978-3-319-60189-2_17.

41. Galván-Arzate $S$, Santamaría A. Thallium toxicity. Toxicol Lett. 1998; 99(1): 1-13.

42. Di Candia D, Muccino E, Battistini A, Boracchi M, Gentile G, Zoja R. Thallium toxicity due to adulterer infusion with thallium sulfate in eight members belonging to the same family nucleus: Autopsy findings and ICP-MS analysis (inductively coupled plasma mass spectrometry) in a triple homicide. Leg Med (Tokyo). 2020; 42: 101661. doi: 10.1016/j.legalmed.2019.101661.

43. Sojakova M, Zigrai M, Karaman A, Plackova S, Klepancova P, Hrusovsky S. Thallium intoxication. Case Report. Neuro Endocrinol. Lett. 2015; 36(4): 311-31.

44. Sharma AN, Nelson LS, Hoffman RS. Cerebrospinal fluid analysis in fatal thallium poisoning: evidence for delayed distribution into central nervous system. Am. J. Forensic Med. Pathol. 2004; 25: 156-8.

45. Aoyama H, Yoshida M, Yamamura Y. Acute poisoning by intentional ingestion of thallous malonate. Hum Toxicol. 1986; 5(6): 389-92.

46. Riyaz R, Pandalai SL, Schwartz M, Kazzi ZN. A fatal case of thallium toxicity: challenges in management. J Med Toxicol. 2013; 9(1): 75-8. doi: 10.1007/s13181-012-0251-1.

47. Yang G, Li C, Long Y, et al. Hair loss evidence to thallium poisoning. Case Rep Emerg Med. 2018.

48. Balan HM, Bohomol AH, Zhminko PH, Bubalo NM, Bubalo VO, Kudriavtseva $\mathrm{AH}$, ta in. Hostri peroralni ta inhaliatsiini otruiennia taliiem i yikh viddaleni naslidky. 2020; 1: 79-90.

49. Locatelli C, Petrolini V. Long-lasting polyneuropathy and psychiatric disorders in thallium poisoning. Study of six cases. Toxicology Letters. 2003; 144(1): 72-4.

50. Balan HM, Bohomol AH, Kravchuk OP, Zhminko PH, Kudriavtseva AH. Kompleksna terapiia hostrykh otruien spolukamy taliiu (Ohliad literatury ta dani vlasnykh doslidzhen). 2020; 2: 40-7. DOI:10.33273/2663-45702020-88-1-71-91

51. Chukhlovina ML. Mediko-gigienicheskie aspekty` nejrotoksichnosti talliya. Gig. i sanitariya. 1999; 4: 38-40. 
52. Osorio-Rico L, Villeda-Hernandez J, Santamaria A, Konigsberg M. The N-Methyl-d-Aspartate Receptor Antagonist MK-801 Prevents Thallium-Induced Behavioral and Biochemical Alterations in the Rat Brain. International J. of Toxicology. 2015; 34(6): 505-13 DOI: 10.1177/1091581815603936.

53. Livanov GA, Ostapenko YuN, Shestova GV, i dr. Znachenie rannej diagnostiki ostry'kh tyazhely 'kh otravlenij soedineniyami talliya na nachal'ny kh stadiyakh intoksikaczii. Toksikol. vestnik. 2011; 5: 1-8.

54. Tsai YT, Huang CC, Kuo HC, et al. Central nervous system effects in acute thallium poisoning. Neurotoxicology. 2006; 27: 291-5.

55. Misra UK, Kalita J. Yadav, Ranjan P. Thallium poisoning: emphasis on early diagnosis and response to haemodialysis. Postgrad Med. J. first published. 2003; 2: 48-50. WWW.postgradmed j com.

56. Kuroda H, Mukai Y, Nishiyama S, Takeshita T, Takeshita T, Tateyama M, et al. Tardily accelerated neurologic deterioration in two-step thallium intoxication. J. Clin Neurosci. 2016; 34: 234-6. DOI: 10.1016/j.jocn.2016.09.003. Epub 2016 Sep. 28.

57. Ostapenko YuN, Livanov GA, Shestova GV, Rutkovskij GV, i dr. Otravlenie soedineniyami talliya (klinika, diagnostika, lechenie) Metod. rekomendaczii. M; 2010. 30 s.

58. Sha S, Kumar R. Thallium poisoning. Presenting as Paresthesias, Paresis, Psychosis and Pain in Abdomen. JAPI. 2006; 54: 53-55.

59. Centers for Disease Control and Prevention (CDC) Thallium poisoning from eating contaminated cake - Iraq, 2008. MMWR Morb Mortal Wkly Rep. 2008; 57: 1015-8.

60. Almassri I, Sekkarie M. Cases of thallium intoxication in Syria: A diagnostic and a therapeutic challenge. Avicenna J Med. 2018; 8(3): 78-81.

61. Livanov GA, Shestova GV, Sukhodolova GN, Batoczy'renov BV, i dr. Klinika, diagnostika i lechenie ostry'kh tyazhyoly'kh otravlenij soedineniyami talliya. Skoraya mediczinskaya pomoshh`. 2019; 3: 9-15.

62. Kuo HC, Huang CC, Tsai YT, et al. Acute painful neuropathy in thallium poisoning. Neurology. $2005 ; 65: 302-4$.

63. Ammendola A, Ammendola E, Argenzio F, et al. Clinical and electrodiagnostic Follow-up of an adolescent poisoned with thallium. Neurol Sci. 2007; 28: 205-8.

64. Poddubny`j N. Otravlenie veka (2012-01-24). https://www.webcitation.org/6DV9upYYYur.

65. Poddubny`j N. Unichtozhit oborotnya. - Kiev. - 2012.

66. Guzhva I, Il'chenko A. Dvenadczat' glavny'kh otravlenij Ukrainy' https://www.webcitation.org/6DV9wfjiRurl. Segodnya.ua. 2009-07-09.

67. «Otruina shkola». Dokumentalnyi serial (vypusk № 205 vid 16 chervnia 2012 roku, NTV).

68. Ostapenko YuN, Livanov GA, Shestova GV, Rutkovskij GV. Otravleniya soedineniyami talliya (klinika, diagnostika i lechenie). Metodicheskie rekomendaczii. M; 2010. 30 s.

69. Yumoto T, Tsukahara K, Naito H, Iida A, Nakao A. A Successfully Treated Case of Criminal Thallium Poisoning. J Clin Diagn Res. 2017 Apr; 11(4): OD01-OD02. doi: 10.7860/JCDR/2017/24286.9494.

70. Al Hammouri F, Darwazeh G, Said A, Ghosh RA. Acute thallium poisoning: series of ten cases. J Med Toxicol. 2011 Dec; 7(4): 306-11. doi:10.1007/s13181-011-0165-3.

71. Yu V, Juhász M, Chiang A, Atanaskova Mesinkovska N. Alopecia and Associated Toxic Agents: A Systematic Review. Skin Appendage Disord. 2018 Oct; 4(4): 245-60. doi: $10.1159 / 000485749$
72. Jiang Y, Xia W, Zhang B, Pan X, Liu W, Jin S, et al. Predictors of thallium exposure and its relation with preterm birth. Environ Pollut. 2018 Feb; 233: 971-976. doi: 10.1016/j.envpol.2017.09.080.

73. Sun TW, Xu QY, Zhang XJ, Wu Q, Liu ZS, Kan QC, et al. Management of thallium poisoning in patients with delayed hospital admission. Clin. Toxicol. (Phila). 2012; 50(1): 65-9.

74. Yang Yongsheng, Faustino PJ, et al. Quantitative determination of thallium binding to ferric hexacyanoferrate: Prussian blue. International J. of Pharmaceutics. 2008; 27 . 291-5.

75. Yu-Tai Tsai, Chin-Chang Huang, et al. Central nervous system effects in acute thallium poisoning. Neuro Noxicjlogy. 2006; 27: 291-5.

76. Guodong Lin PhD, Luo Yuan PhD, Lili Bai BM, Yanging Liu BM, Yongan Wang PhD, Zewu Qiu Ph.D. Successful treatment of a patient with severe thallium poisoning in a coma using Prussian blue and plasma exchange. Medicine (Baltimore). 2019 Feb; 98(8): e 14629. DOI: 10.1097/MD.0000000000014629. PMCID: PMC 6407929. PMID 30813198.

77. Osorio-Rico L, Santamaria A, Galván-Arzate S. Thallium Toxicity: General Issues, Neurological Symptoms, and Neurotoxic Mechanisms. Adv Neurobiol. 2017; 18: 34553. doi: 10.1007/978-3-319-60189-2 17.

78. Ghaderi A, Vahdati-Mashhadian N, Oghabian Z, et al. DARU journal of Pharmaceutical Sciences. 2015; 23: 39.

79. Questel F, Dugarin J, Dally S. Thallium-contaminated heroin. Ann intern Med. 1996; 124 (6): 616.

80. Rees HG. Organophosphates, sheep dip and ill health in farmers. Hum. and Exp. Toxicol. 1998; 17(9): 487.

81. Karalliedde L, Senanayake N. Organophosphorous insecticide poisoning. J. Int. Fed. Clin. Chem. 1999; 11: 1-9.

82. Vucinic S, Joksovic D, Todorovic V. Acute organophosphate insecticide poisoning; Antidotes and intensive care management J. Clin. Toxicol. 2003; 41(4): 444-5.

83. Valevskij VS, Shinkarenko ND, Dubovskaya NG, Borisova IS. K diagnostike nejropatij, obuslovlenny'kh toksicheskim vozdejstviem fosfororganicheskikh soedinenij, obladayushhikh otdalennoj nejrotoksichnost yu. Sovremen. probl. toksikol. 2003; 2: 77-9.

84. Aardema H, Meertens JHJM, Ligtenberg JJM, PetersPolman OM, Tulleken JE, Zijlstra JG. Organophosphorus pesticide poisoning: cases and developments. Netherlands J Med. 2008; 66(4): 149-53.

85. Corriols M, Marin L, Berroteran J. Incidence of acute pesticide poisoning in Nicaragua: A public health concern. Occup. and Environ. Med. 2009; 66(3): 205-10.

86. Balan GM, Kharchenko OA, Lepeshkin IV, i dr. Ostroe gruppovoe otravlenie vinogradarej bakovoj smes'yu pesticzidov. Materialy` XV s`ezda gigienistov Ukrainy`; 2012 g. cent. 20-21; L'vov. 2012, S. 408-9.

87. Kharchenko OA, Balan GM, Bubalo NN. Ostry`e otravleniya fosfororganicheskimi soedineniyami: osnovny'e klinicheskie sindromy' i mekhanizmy' ikh formirovaniya (obzor literatury' i danny'e sobstvenny'kh issledovanij). Sovremenny`e problemy` toksikologii pishhevoj i khimicheskoj bezopasnosti. 2014; 5(68): 14-28.

88. Díaz-Resendiz KJG, Toledo-Ibarra GA, Girón-Pérez MI. Modulation of Immune Response by Organophosphorus Pesticides: Fishes as a Potential Model in Immunotoxicology. Hindawi Publishing Corporation. Journal of Immunology Research. 2015; 10 p.

89. Biomarkery` i oczenka riska: konczepczii i princzipy 
(Gigienicheskie kriterii sostoyaniya okruzhayushhej sredy`; 155). Sovmestnoe izdanie Programmy` OON po okruzhayushhej srede, Mezhdunarodnoj organizaczii truda i Vsemirnoj organizaczii zdravookhraneniya. Vsemirnaya organizacziya zdravookhraneniya, Zheneva. 1996; $96 \mathrm{s.}$

90. Zabrodskij PF. Immunotoksikologiya fosfororganicheskikh soedinenij. Saratov. Izdatel'stvo «Saratovskij istochnik»; 2016, $289 \mathrm{~s}$

91. Ustinova LA, Seredynska NM, Kurdil NV. Toksykanty antykholinesteraznoi dii: mekhanizm dii, klinichni oznaky ta aktualni pytannia zabezpechennia zasobamy antydotnoi terapii. Suchasni problemy toksykolohii, kharchovoi ta khimichnoi bezpeky. 2017; 3(79): 73-82.

92. Boltneva NP, Rudakova EV, Sigolaeva LV, Makhaeva GF. Esterase Status of Various Species in Assessment of Exposure to Organophosphorus Compounds Toxicological Problems. Dishovsky C, Radenkova-Saeva J, editors. Bulgarian Toxicological Society. Military Publishing House; Sofia, Bulgaria. 2014, P. 27-38.

93. Fedchenko OV, Zhminko PH. Biomarkery ekspozytsii ta efektu fosfororhanichnykh spoluk (ohliad danykh literatury ta rezultaty vlasnykh doslidzhen). Ukrainskyi zhurnal suchasnykh problem toksykolohii. 2018; 4: 19-35.

94. Shumeiko VM. Ekolohichna toksykolohiia i teroryzm. Biotoksykanty. K.: ЭKOREHIO-ETKhi; 2002. S. 4-27.

95. Weinstein RS, Alibek K. Biological and Chemical Terrorism. Thieme. 2003; 114-47.

96. Golikov SN, Rozengard VI. Kholine'sterazy' i antikholine`sterazny`e veshhestva. L.: Mediczina; 1964. 140 s.

97. Golikov SN. Rukovodstvo po toksikologii otravlyayushhikh veshhestv. M.: Mediczina; 1972. 470 s.

98. Kurlyandskij BA, Filov VA, Kagan YuS, Kokshareva NV, Zhmin 'ko PG. Blokatory` kholine`sterazy`. Obshhaya toksikologiya. M.: Mediczina; 2002. S. 176-236.

99. Karbamatny`e pesticzidy`: obshhee vvedenie. Gigienicheskie kriterii sostoyaniya okruzhayushhej sredy'. Mezhdunarodnaya programma po khimicheskoj bezopasnosti; 64. Materialy` VOZ. Zheneva. M.: Mediczina. 1991. 126 s.

100. Kagan YuS. Toksikologiya fosfororganicheskikh pesticzidov. M.: Mediczina; 1977. S. 48-73.

101. Maxwell DM, Lenz DE, Ballantyne B, Marrs TC. Structure-activity relationships and anticholinesterase activity. Clinical and Experimental Toxicology of Organophosphates and Carbamates. Oxford: ButterwordHeinemann Ltd; 1992. P. 47-58.

102. Brestkina AP, Rozengart VI, Sherstobitov OE. Izbiratel'naya toksichnost' fosfororganicheskikh insektoakariczidov. Sravnitel'no-biokhimicheskie aspekty'. L.: Nauka, Leningradskoe otd.; 1978. 173 s.

103. Ballantyne B, Marrs TC, Aldridge WN. Clinical and Experimental Toxicology of Organophosphates and Carbamates. Oxford: Butterword-Heinemann Ltd; 1992. $641 \mathrm{p}$.

104. Fosfororganicheskie insekticzidy: obshhee vvedenie. Gigienicheskie kriterii sostoyaniya okruzhayushhej sredy'; 63. Materialy' VOZ. Zheneva. M.: Mediczina. 1990. 167 s.

105. Golikov SN, Kuzneczov SG. Sovremenny`e predstavleniya o prirode kholinoreczeptora. Vestnik AMN SSSR. 1970; 2: 67-85.

106. Anichkov SV. Izbiratel'noe dejstvie mediatorny'kh sredstv. L.: Mediczina; 1974. $295 \mathrm{~s}$.

107. Prozorovskij VB, Savateev NV. Neantikholine`sterazny`e mekhanizmy' dejstviya antikholine`sterazny'kh veshhestv. M.: Mediczina, 1976. $160 \mathrm{~s}$.
108. Luzhnikov EA. Ostry`e otravleniya: Rukovodstvo dlya vrachej. M.: Mediczina; 2000. 434 s.

109. Kuczenko SA. Osnovy` toksikologii: Nauchno-metodicheskoe izdanie. SPb.: OOO Izd. «Foliant»; 2004. $720 \mathrm{~s}$.

110. Rosenberg YJ. A pretreatment or post exposure treatment for exposure to a toxic substance by pulmonary delivery (inhaler) of a bioscavenger. PCT Int. Appl. (WO 2005000195 A2). 2005; 6(1): 22.

111. Ballantyne B, Marrs TC, D'Mello DG. Neurobehavioural toxicology of anticholinesterases. Clinical and experimental toxicology of organophosphates and carbamates. Oxford: Butterworth-Heinemann Ltd; 1992. 61-75.

112. Johnson MK. Improved assay of neurotoxic esterase for screening organophosphates for delayed neurotoxicity potential. Arch. Toxicol. 1977; 37: 113-5.

113. Lotti M, Becker CE, Aminoff MY. Organophosphate polyneuropathy: pathogenesis and prevention. Neurology. 1984; 34: 658.

114. Ballantyne B, Marrs TC, Johnson MK. Molecular events in delayed neuropathy: experimental aspects of neuropathy target esterase. Clinical and Experimental Toxicology of Organophosphates and Carbamates. Oxford: ButterwordHeinemann Ltd; 1992, 90-113.

115. Tkachenko II, Kokshareva NV, Kagan YuS, et al. A study of the delayed neurotoxic effect of a new organophosphorous fungicide 0,0-diphenyl-1-acetoxy-2,2,2-trichlorethylphosphonate (aphos). Communication 1. Clinical manifestations and neurotoxic esterase inhibition. Fresenius Env. Bul. 1992; 1: 571-6.

116. Tkachenko II, Kokshareva NV, Kagan YuS, et al. A study of the delayed neurotoxic effect of a new organophosphorous fungicide 0,0-diphenyl-1-acetoxy-2,2,2-trichlorethylphosphonate (aphos). Communication 2. Electrophysiological and morpholodical investigations. Fresenius Env. Bul. 1993; 2: 131-6.

117. Prodanchuk NG, Kokshareva NV. Dostizheniya v oblasti izucheniya mekhanizmov dejstviya i prognozirovaniya otdalenny'kh nejropatij, vy`zvanny $k h$ fosfororganicheskimi soedineniyami. Sovrem. probl. toksikol. 2001; 3: 3-8.

118. Glynn P. A mechanism for organophosphate-induced delayed neuropathy 42 Congress of the European Societies of Toxicology. Cracow, 2005. Sept 11-14. Paul Glynn. Toxicol. Lett. 2006; 162(1): 94-7.

119. Hayes WJ. Pesticides studied in man. Baltimor, London: Williams and Wilkins; 1982. $672 \mathrm{p}$.

120. Casida JE, Nomura DK, Vose SC, Kazutoshi F. Organophosphate-sensitive lipases modulate brain lysophospholipids, ether lipids and endocannabinoids. Chem. Biol. Interact. 2008; 175: 1-3.

121. Zhmin 'ko PG, Korol ' VM, Kolyadenko VG, Prodanchuk MG. Sposob profilaktiki oslozhnenij otdalenny'kh nejropatij, vy`zvanny`kh nejroparaliticheskimi fosfororganicheskimi veshhestvami. Patent na izobretenie №38876 A ot $15.05 .2001 \mathrm{~g}$.

122. Zhmin `ko PG. Rol immunnoj sistemy` $v$ patogeneze otdalennoj nejrotoksichnosti nekotory'kh fosfororganicheskikh soedinenij. Sovremenny`e problemy' toksikologii. 1999; 4: 18-24.

123. Zhminko PH, Loboda YuI. Doslidzhennia efektyvnosti tsyklofosfanu v poperedzhenni pareziv i paralichiv pry viddalenii neirotoksychnii dii fosfororhanichnykh rechovyn. Sovremenny`e problemy` toksikologii. $2003 ; 2$ : 72-3.

124. Zhminko PG, Kokshareva NV. Delayed Neurotoxicity Induced by Organophosphates: Experimental Correction of Neuropathy. Toxicological Problems. Sofia, Bulgaria: Publishing Hous Irita; 2011, 175-83. 


\title{
PROBLEM ARTICLES
}

\section{ДО ОБГРУНТУВАННЯ ПЕРЕЛІКУ НЕБЕЗПЕЧНИХ ВИСОКОТОКСИЧНИХ ХІМІЧНИХ РЕЧОВИН, ЯКІ ПІДЛЯГАЮТЬ ОСОБЛИВОМУ КОНТРОЛЮ ЩОДО ОБІГУ, ЗБЕРІГАННЯ, ВИКОРИСТАННЯ ТА УТИЛІЗАЦІЇ \\ Частина 1 (рицин, сполуки талію та фосфорорганічні сполуки)}

\author{
М.Г. Проданчук ${ }^{1}$ Г.М. Балан ${ }^{1}$, О.П. Кравчук ${ }^{1}$ П.Г. Жмінько ${ }^{1}$ І.М. Максимчук², Н.П. Чермних ${ }^{1}$ \\ ${ }_{1}^{1}$ ДП «Науковий центр превентивної токсикології, харчової та хімічної безпеки \\ імені академіка Л.І. Медведя МОЗ України», м Київ, Україна \\ ${ }^{2}$ Національна поліція України, м. Київ, Україна
}

PEЗЮМЕ. Мета роботи. На підставі аналітичного огляду літературних даних виділити групу високотоксичних хімічних речовин, котрі за останні десятиліття найчастіше використовуються в умисних кримінальних та суїцидальних інцидентах, диверсійних і терористичних актах, обіг, зберігання, використання та утилізацію яких потрібно особливо прискіпливо контролювати правоохоронним органам.

Матеріали та методи. Аналітичний огляд наукових публікацій виконаний з використанням реферативних баз даних наукових бібліотек Pub Med, Medline і текстових баз даних наукових видавництв Elsevier, Pub Med, Central, BMJ group ma інших VIP-баз даних. Використано методи системного, порівняльного та контент-аналізу.

Результати та висновки. Проаналізовано наукові публікації щодо небезпечних високотоксичних хімічних речовин, які за останні чверть сторіччя найчастіше використовуються у світі, зокрема в умисних кримінальних та суїциальних інцидентах, диверсійних і терористичних актах. Установлено, що до них переважно відносяться: рицин, сполуки талію, фосфорорганічні сполуки та бойові отруйні речовини, миш'як і його сполуки, ціаніди та неорганічні водорозчинні сполуки ртуті (сулема, мертіолят натрію), а також пестициди паракват і дикват. На основі аналізу їхньої токсичності, клінічних та морфологічних проявів інтоксикації за різних шляхів надходження до організму обгрунтовано необхідність внесення їх до Переліку особливо небезпечних хімічних речовин, обіг яких, зберігання, використання та утилізація потребують більш жорсткого контролю правоохоронних органів. У першій частині даної статті представлені рицин, сполуки талію, фосфорорганічні сполуки та бойові отруйні речовини.

Ключові слова: високотоксичні небезпечні хімічні речовини, рицин, сполуки талію, фосфорорганічні сполуки.

\section{К ОБОСНОВАНИЮ ПЕРЕЧНЯ ОПАСНЫХ ВЫСОКОТОКСИЧНЫХ ХИМИЧЕСКИХ ВЕЩЕСТВ, ТРЕБУЮЩИХ ОСОБОГО КОНТРОЛЯ НАД ИХ ОБОРОТОМ, ХРАНЕНИЕМ, ИСПОЛЬЗОВАНИЕМ И УТИЛИЗАЦИЕЙ \\ Часть 1 (рицин, соединения таллия и фосфорорганические соединения) \\ Н.Г. Проданчук, Г.М. Балан ${ }^{1}$, А.П. Кравчук ${ }^{1}$, П.Г. Жминько ${ }^{1}$, И.Н. Максимчук ${ }^{2}$, Н.П. Чермных 1 \\ ${ }^{1}$ ДП «Научный центр превентивной токсикологии, пищевой и химической безопасности имени академика Л.И. Медведя МЗ Украины», г. Киев, Украина \\ ${ }^{2}$ Национальная полиция Украины, г. Киев, Украина}

PЕЗЮМЕ. Цель работы. На основании аналитического обзора литературных данных выделить группу высокотоксичных химических веществ, которые за последние десятилетия чаще всего используются в преднамеренных криминальных и суииидальных инцидентах, диверсионных и террористических актах, оборот, хранение, использование и утилизация которых требуют особенно жесткого контроля правоохранительных органов.

Материалы и методы. Аналитический обзор научных публикаций выполнен с использованием реферативных баз данных научных библиотек Pub Med, Medline и текстовых баз данных научных издательств Elsevier, Pub Med, Central, BMJ group и других VIP-баз данных. Использованы методы системного, сравнительного и контент-анализа.

Результаты и выводы. Проанализированы научные публикации по опасным высокотоксичным химическим веществам, которые за последние 25 лет наиболее часто используются в мире, в частности в преднамеренных криминальных и суицидальных инцидентах, диверсионных и террористических актах и установлено, что к ним относятся преимущественно рицин, соединения таллия, фосфорорганические соединения и боевые отравляющие вещества, мышьяк и его соединения, цианиды и неорганические водорастворимые соединения ртути (сулема, мертиолят натрия), а также пестициды паракват и дикват. На основе анализа их токсичности, клинических и морфологических проявлений интоксикации при различных путях поступления в организм обоснована необходимость внесения их в перечень особо опасных химических веществ, оборот которых, хранение, использование и утилизация требуют более жесткого контроля правоохранительных органов. В первой части данной статьи представлены рицин, соединения таллия, фосфорорганические соединения и боевые отравляющие вещества.

Ключевые слова: высокотоксичные опасные химические вещества, рицин, соединения таллия, фосфорорганические соединения.

Received 11.23.2020 